\title{
The Electrogenic Sodium Bicarbonate Cotransporter NBCe1 Is a High-Affinity Bicarbonate Carrier in Cortical Astrocytes
}

\author{
Shefeeq M. Theparambil, ${ }^{1}$ Iván Ruminot, ${ }^{1}$ Hans-Peter Schneider, ${ }^{1}$ Gary E. Shull, ${ }^{2}$ and Joachim W. Deitmer ${ }^{1}$ \\ ${ }^{1}$ Abteilung für Allgemeine Zoologie, FB Biologie, University of Kaiserslautern, P.B. 3049, D-67653 Kaiserslautern, Germany, and ${ }^{2}$ Department of Molecular \\ Genetics, Biochemistry and Microbiology, University of Cincinnati, Cincinnati, Ohio 45267
}

The electrogenic sodium bicarbonate cotransporter NBCe1 (SLC4A4) is a robust regulator of intracellular $\mathrm{H}^{+}$and a significant base carrier in many cell types. Using wild-type (WT) and NBCe1-deficient (NBC-KO) mice, we have studied the role of NBCe1 in cortical astrocytes in culture and in situ by monitoring intracellular $\mathrm{H}^{+}$using the $\mathrm{H}^{+}$-sensitive dye BCECF $\left[2^{\prime}, 7^{\prime}\right.$-bis-(carboxyethyl)-5-(and-6)carboxyfluorescein] in wide-field and confocal microscopy. Adding 0.1-3 $\mathrm{mM} \mathrm{HCO}_{3}^{-}$to an $\mathrm{O}_{2}$-gassed, HEPES-buffered saline solution lowered the intracellular $\mathrm{H}^{+}$concentration with a $K_{\mathrm{m}}$ of $0.65 \mathrm{mM} \mathrm{HCO}_{3}^{-}$in WT astrocytes, but slowly raised $\left[\mathrm{H}^{+}\right]_{\mathrm{i}}$ in $\mathrm{NBCe}-\mathrm{KO}_{0}$ astrocytes. Human NBCe1 heterologously expressed in Xenopus oocytes could be activated by adding $1-3 \mathrm{~mm} \mathrm{HCO}_{3}^{-}$, and even by residual $\mathrm{HCO}_{3}^{-}$in a nominally $\mathrm{CO}_{2} / \mathrm{HCO}_{3}^{-}$-free saline solution. Our results demonstrate a surprisingly high apparent bicarbonate sensitivity mediated by NBCe1 in cortical astrocytes, suggesting that NBCe1 may operate over a wide bicarbonate concentration in these cells.

Key words: bicarbonate; glial cells; NBCe1-KO; pH; proton concentration; Xenopus oocytes

\section{Introduction}

The electrogenic sodium bicarbonate cotransporter NBCe1 (SLC4A4) is one of the major regulators of intracellular proton concentration $\left(\left[\mathrm{H}^{+}\right]_{\mathrm{i}}\right)$ in many cell types, but particularly in epithelial tissue and brain (Deitmer and Rose, 1996; Chesler, 2003). In the brain, NBCe1 is expressed in most cell types, with most prominent expression in astrocytes (Deitmer and Chesler, 2009; Majumdar and Bevensee, 2010), and the stoichiometry has been suggested to be one $\mathrm{Na}^{+}$cotransported with two $\mathrm{HCO}_{3}^{-}$(Deitmer and Schlue, 1989; Romero and Boron, 1999). Depending on the ion distribution in these cells, the reversal potential of NBCe1 ranges between -50 and $-90 \mathrm{mV}$, which would allow the carrier to function in both directions across the cell membrane. Thus, it would appear that NBCe1 activity can contribute to intracellular as well as extracellular acid/base homeostasis in the brain and could, therefore, have a significant impact on neuronal activity. Mutations in the SLC4A4 gene are associated with pathophysiological states in several different organs. For example, defective expression of NBCe1 in astrocytes, due to homozygous mutation of the SLC4A4 gene, has been shown to cause familial migraine

\footnotetext{
Received June 5, 2013; revised Dec. 9, 2013; accepted Dec. 11, 2013.

Author contributions: S.M.T., I.R., and J.W.D. designed research; S.M.T., I.R., and H.-P.S. performed research; G.E.S. contributed unpublished reagents/analytic tools; S.M.T., I.R., H.-P.S., and J.W.D. analyzed data; S.M.T., I.R., G.E.S., and J.W.D. wrote the paper.

This study was supported by grants from the Deutsche Forschungsgemeinschaft (DE 231/24-1), and the Research Initiative of Membrane Proteins of the University of Kaiserslautern (to J.W.D.). We are grateful to Dr. Frank Kirchhoff, Hombur/Saar, Germany, for providing the GFRT transgenic mice; and to Dr. Ursula Seidler, Hannover, Germany, for helping with the breeding of NBCe1-K0 mice. We thank Dr. Holger M. Becker, Kaiserslautern, for critically reading an early version of this manuscript.

The authors declare no competing financial interests.

Correspondence should be addressed to Joachim W. Deitmer, Abteilung für Allgemeine Zoologie, FB Biologie, University of Kaiserslautern, P.B. 3049, D-67653 Kaiserslautern, Germany. E-mail: deitmer@biologie.uni-kl.de.

DOI:10.1523/JNEUROSCI.2377-13.2014

Copyright $\odot 2014$ the authors $\quad 0270-6474 / 14 / 341148-10 \$ 15.00 / 0$
}

(Suzuki et al. 2010; Russel and Ducros 2011), and chronic proximal renal tubular acidosis and ocular abnormality are also reported to be associated with SLC4A4 mutation and NBCe1 dysfunction (Igarashi et al., 1999).

Here we have studied cortical astrocytes in culture and in acute tissue slices of wild-type (WT) and NBCe1-deficient (NBCe1-KO) mice, monitoring $\left[\mathrm{H}^{+}\right]_{\mathrm{i}}$ with the $\mathrm{H}^{+}$-selective dye BCECF $\left[2^{\prime}, 7^{\prime}\right.$ bis-(carboxyethyl)-5-(and-6)-carboxyfluorescein]. Our results reveal that $\left[\mathrm{H}^{+}\right]_{\mathrm{i}}$ regulation was highly sensitive to external bicarbonate, and NBCe1-mediated $\left[\mathrm{H}^{+}\right]_{\mathrm{i}}$ regulation was even detected in saline solution without added $\mathrm{HCO}_{3}^{-}$("nominally $\mathrm{HCO}_{3}^{-}$-free"). Comparing astrocytes and tissue slices from WT and NBCe1deficient mice indicated that this high bicarbonate sensitivity was attributable to the activity of NBCe1.

\section{Materials and Methods}

Chemicals and reagents. Standard chemicals, tissue culture reagents, EIPA (ethyl-isopropyl amiloride), DIDS (4,4'-diisothiocyano-2,2' stilbenedisulfonic acid), and EZA (6-ethoxy-1,3-benzothiazole-2sulfonamide) were purchased from Sigma. BCECF-AM was obtained from Invitrogen.

Animals, primary astrocyte culture, and acute slices from cerebral cortex. Astrocyte cultures from wild-type [C57BL/6, postnatal day 0 (P0) to P3] and NBCe1-KO (129S6/SvEv and Black Swiss background, P0-P3) mouse cerebral cortex were prepared as previously described in detail (Stridh et al., 2012). Astrocytes were plated on poly-D-lysine-coated glass coverslips and maintained in DMEM containing 5\% fetal calf serum and $5 \%$ horse serum. The medium was renewed completely after $24 \mathrm{~h}$ of plating and subsequently every $3 \mathrm{~d}$. Cells were used for experiments when they were $10-20 \mathrm{~d}$ old in culture.

Acute cortical slices were prepared from WT NMRI (New Medical Research Institute) mice, and from mice ("GFRT") that were genetically modified by expressing a monomeric red fluorescent protein (mRFP1) under control of the human glial fibrillary acidic protein promotor in astrocytes (Hirrlinger et al., 2005). Cortical slices from NBCe1-KO mice 

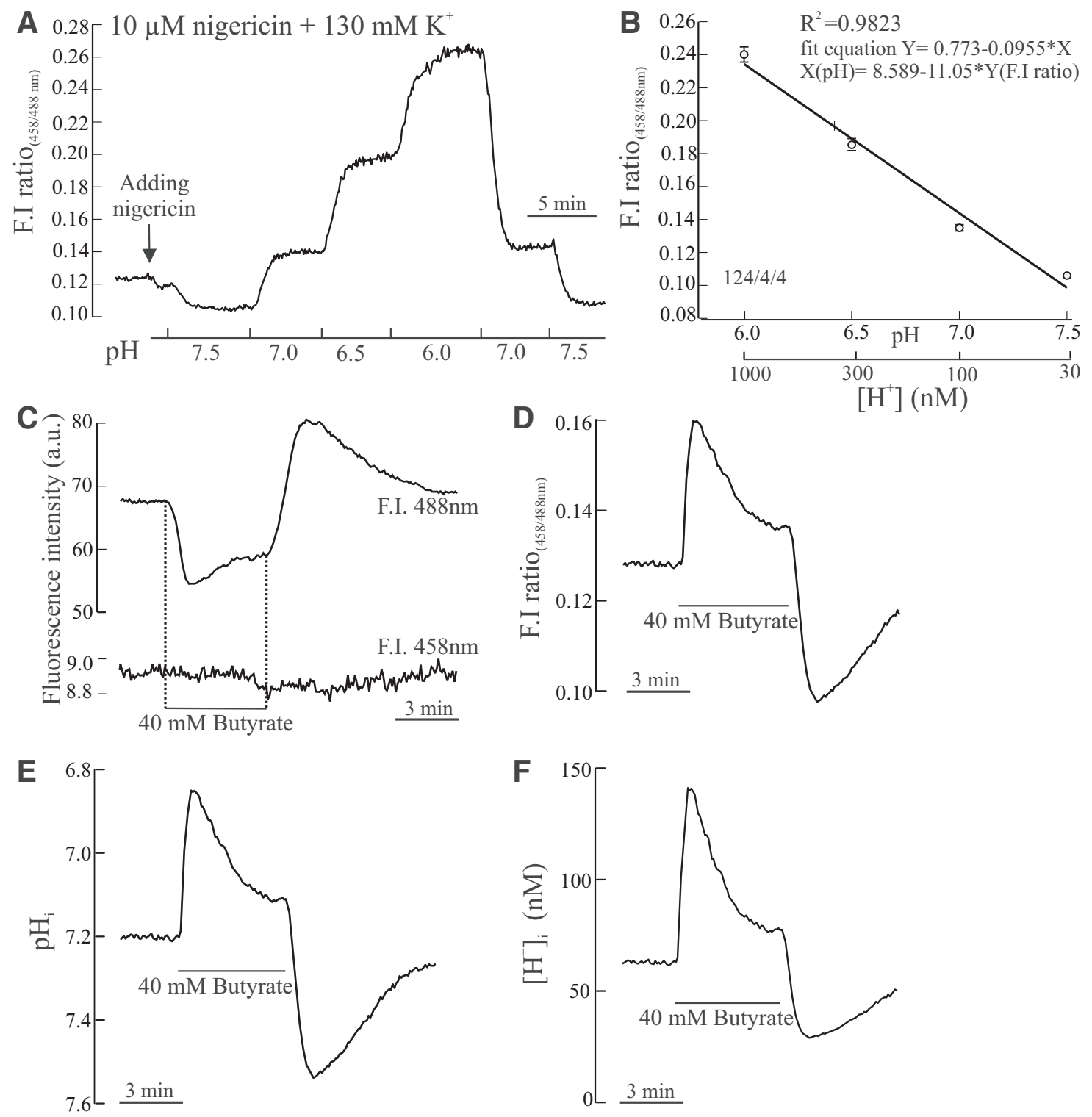

Figure 1. Calibration of the $\mathrm{H}^{+}$-sensitive fluorescence signal in cultured cortical astrocytes. $A, B$, Calibration of the $F I$ ratio signal $(\boldsymbol{A})$ in the presence of nigericin and $130 \mathrm{~mm} \mathrm{~K}{ }^{+}$to equilibrate $\mathrm{K}^{+}$and $\mathrm{H}^{+}$across the cell membrane, monitored at different extracellular $\mathrm{pH}$ values, and plotted against the $\mathrm{pH}$ value and the respective $\mathrm{H}^{+}$concentration $(\boldsymbol{B})$. Numbers of cells/cultures/animals as used in the experiments are indicated in the plot, as well as the coefficient of correlation $\left(R^{2}\right)$ and the fit equation $(\boldsymbol{B})$. $\boldsymbol{C}-\boldsymbol{F}$, The fluorescence recording during application of $40 \mathrm{~mm}$ butyrate, at $\mathrm{pH}$ 7.4, showing the two recorded wavelengths in arbitrary units (a.u.; $\boldsymbol{C}$, the ratio of the fluorescence at the two wavelengths $(\boldsymbol{D})$, converted to the $\mathrm{pH}_{\mathrm{i}}(\boldsymbol{E})$, and to $\left[\mathrm{H}^{+}\right]_{\mathrm{i}}(\boldsymbol{F})$.

showed the same BCECF loading pattern as WT mice. Astrocyte cultures and acute cortical slices from NBCe1-KO mice were prepared after animals were genotyped by PCR analysis (Gawenis et al., 2007).

Wild-type and NBCe1-KO animals from postnatal day 15-20 were decapitated and their brains were quickly transferred to an ice-cold, $\mathrm{Ca}^{2+}$-reduced artificial CSF (aCSF), containing the following (in $\mathrm{mm}$ ): $\mathrm{NaCl} 125, \mathrm{KCl} 2.5, \mathrm{NaH}_{2} \mathrm{PO}_{4} 1.25, \alpha$-D-glucose 25, $\mathrm{MgCl}_{2} 2.5, \mathrm{CaCl}_{2}$ 0.5, $\mathrm{NaHCO}_{3} 26$, aerated with $5 \% \mathrm{CO}_{2} / 95 \% \mathrm{O}_{2}$ to maintain the $\mathrm{pH}$ at 7.4 . Coronal cortical slices of GRFT and NBC-KO animals were obtained at a thickness of $150 \mu \mathrm{m}$ using a vibratome (VT 1000, Leica), and were stored in aCSF for $60 \mathrm{~min}$ at $30^{\circ} \mathrm{C}$.

The animals were maintained on a $12 \mathrm{~h}$ day/night cycle at constant room temperature with ad libitum access to water and standard mouse fodder in the animal facility of the Technical University of Kaiserslautern. All procedures involving animals were approved by the Landesuntersuchungsamt Rheinland-Pfalz, Koblenz (23 177-07).

Protein extraction, immunoblot analysis, and immunocytochemistry. Immunoblot analysis was performed to compare the NBCe1 protein expression level in WT and NBCe1-KO murine astrocytes. Cultured cor- tical astrocytes from NBCe1-KO and littermate WT mice were collected separately, and lysed in $2 \%$ SDS solution containing protease inhibitors (Roche Diagnostics). Total protein content was determined using a BCA protein assay kit (Thermo Scientific). For immunoblotting, protein samples $(50 \mu \mathrm{g})$ were loaded on to $4-20 \%$ Run Blue SDS Gel (Biozol Diagnostica Vertrieb) and electrotransferred onto nitrocellulose membranes. Blots were probed with anti-NBCe1 rabbit polyclonal antibody (Ab; diluted 1:500; anti-SLC4A4, Abcam) and visualized with a peroxidaseconjugated goat anti-rabbit IgG secondary antibody (diluted 1:2000; Santa Cruz Biotechnology). The signal was detected using a chemiluminescence kit (Lumi-Light, Roche) with a Versa Doc imaging system (Bio-Rad).

For marking cultured cortical astrocytes for expression of NBCe1, antibodies against NBCe1 attached to goat-anti-rabbit Alexa Fluor 488 antibody were used (Invitrogen/Molecular Probes). In brief, cells were fixed in $4 \%$ paraformaldehyde for $10 \mathrm{~min}$ at room temperature (RT). After washing the cells three times with PBS, cells were permeabilized with $0.1 \%$ Triton-X for $10 \mathrm{~min}$ at RT. Cells were then incubated with blocking solution containing $10 \%$ normal goat serum, $3 \%$ bovine serum 
albumin and $0.1 \%$ Triton-X to reduce unspecific antibody binding, for $1 \mathrm{~h}$ at RT. Cells were then incubated with primary antibody against NBCe1 (rabbit anti-SLC4A4 antibody, Abcam). After washing out the primary antibody with PBS, cells were incubated for $1 \mathrm{~h}$ with goat-anti rabbit antibody conjugated with $\mathrm{Al}-$ exa Fluor 488 and Hoechst $(5 \mu \mathrm{g} / \mathrm{ml})$ for 15 min as cell nuclei marker. The fluorescence signals were detected by using a LSM-710 confocal microscope (Zeiss).

Intracellular $\mathrm{H}^{+}$imaging. To measure the intracellular $\mathrm{H}^{+}$concentration $\left(\left[\mathrm{H}^{+}\right]_{\mathrm{i}}\right)$ changes in cultured cortical astrocytes, we used a confocal imaging system and acetoxymethyl ester of a proton-sensitive dye, BCECF-AM. The dye was loaded into the cells by incubating them with $3 \mu \mathrm{M}$ BCECF-AM in HEPES-buffered saline solution for $15 \mathrm{~min}$ at room temperature. Cells were then mounted on a closed chamber of the confocal laser scanning microscope (LSM 510, Zeiss) and superfused continuously either with HEPES-buffered (in mM) $\mathrm{NaCl} 140$, $\mathrm{KCl} 5, \alpha$-D-glucose $10, \mathrm{NaH}_{2} \mathrm{PO}_{4}$ 0.5, HEPES $10, \mathrm{MgCl}_{2}$ 1, and $\mathrm{CaCl}_{2} 2$, or the following $\mathrm{CO}_{2} / \mathrm{HCO}_{3}^{-}$-buffered saline solution (in $\mathrm{mM}$ ): $\mathrm{NaCl} 114, \mathrm{KCl} 5, \mathrm{NaH}_{2} \mathrm{PO}_{4} 0.5, \alpha$-D-glucose $10, \mathrm{NaHCO}_{3} 26\left(21\right.$ at $\left.35^{\circ} \mathrm{C}\right), \mathrm{MgCl}_{2} 1$, and $\mathrm{CaCl}_{2}$ 2. BCECF was excited consecutively at $488 \mathrm{~nm}$ (proton-sensitive wavelength) and 458 $\mathrm{nm}$ (close to isosbestic point), and the changes in fluorescence emission were monitored at $>505 \mathrm{~nm}$ (using LP 505 filter). Images were obtained every $5 \mathrm{~s}(0.2 \mathrm{~Hz})$ with a $40 \times$ waterimmersion objective. The fluorescence emission intensity of $488 \mathrm{~nm}$ excitation changes inversely with a change in $\left[\mathrm{H}^{+}\right]_{\mathrm{i}}$, whereas the fluorescence emission intensity of $458 \mathrm{~nm}$ excitation is largely $\mathrm{pH}$ insensitive. The changes in $\left[\mathrm{H}^{+}\right]_{\mathrm{i}}$ were monitored using the ratio $F_{(458)} /$ $F_{(488)}$. The ratio was converted into $\mathrm{pH}$ and absolute intracellular proton concentrations $\left(\left[\mathrm{H}^{+}\right]_{\mathrm{i}}\right)$ by using the nigericin-based calibration technique (Fig. 1A). Cells were perfused with calibration solutions, containing nigericin $10 \mu \mathrm{M}, \mathrm{NaCl} 15 \mathrm{~mm}, \mathrm{KCl} 130$ mM, HEPES $20 \mathrm{~mm}, \mathrm{MgCl}_{2} 1 \mathrm{~mm}$ and $\mathrm{CaCl}_{2} 1 \mathrm{~mm}$, at $\mathrm{pH}$ 6.0, 6.5, 7.0, and 7.5. The mean ratio values $\left(F_{(458)} / F_{(488)}\right.$ were plotted as a function of $\mathrm{pH}$ to create the calibration curve (Fig. $1 B$ ). As a recording example, the changes in fluorescence intensity (FI) at the two wavelengths following application of $40 \mathrm{~mm}$ butyrate at a constant saline solution $\mathrm{pH}$ of 7.4 are shown in Figure $1 C$, and after forming the FI ratio (Fig. 1D). The ratio was then converted to intracellular $\mathrm{pH}\left(\mathrm{pH}_{\mathrm{i}}\right.$; Fig. $\left.1 E\right)$ and $\left[\mathrm{H}^{+}\right]_{\mathrm{i}}($ Fig. $1 F)$.

Acute cortical slices were loaded with $4 \mu \mathrm{M}$ BCECF-AM in aCSF saline solution for $30 \mathrm{~min}$ at $30^{\circ} \mathrm{C}$. The slices were mounted on a perfusion chamber of an upright microscope (BX50WI, Olympus) equipped with an epifluorescence unit (Polychrome IV, Till Photonics). The slices were superfused continuously with aCSF and subsequently changed to HEPES-buffered saline solution as follows (in $\mathrm{mm}$ ): $\mathrm{NaCl} \mathrm{136,} \mathrm{KCl} 3$, $\alpha$-D-glucose 2, L-lactate 1, HEPES $10, \mathrm{MgSO}_{4} 1,25$ and $\mathrm{CaCl}_{2} 1,25, \mathrm{pH}$ 7.4. BCECF was excited at 440 and $490 \mathrm{~nm}$ for $5 \mathrm{~ms}$ at an interval of $5 \mathrm{~s}$. The $535 \mathrm{~nm}$ fluorescence emission of the two excitation wavelengths was monitored through a $40 \times$ water-immersion objective with a Peltiercooled CCD camera (Till Photonics). The ratio of BCECF emissions $F_{(440)} / F_{(490)}$ was converted into a proton concentration using nigericinbased calibration method as described above. Most measurements were performed at room temperature $\left(22^{\circ} \mathrm{C}\right)$, while some experiments were performed at $35^{\circ} \mathrm{C}$ as indicated, with the $\left[\mathrm{HCO}_{3}^{-}\right]$being $21 \mathrm{~mm}$ at $5 \%$ $\mathrm{CO}_{2}$ to maintain the $\mathrm{pH}$ value at 7.4 due to lower $\mathrm{CO}_{2}$ solubility at higher temperature. It should be noted that at $35^{\circ} \mathrm{C}$ the saline solution $\mathrm{pH}$ value

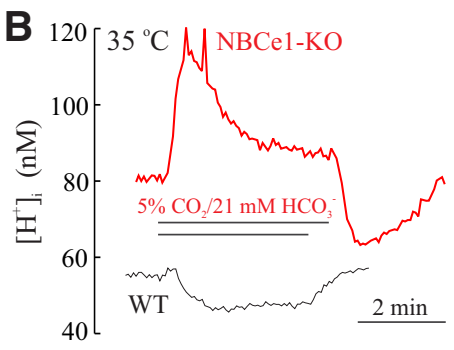

Amplitude of alkalinization as induced by removal of $5 \% \mathrm{CO}_{2} / 26 \mathrm{mM} \mathrm{HCO}_{3}$

$$
\begin{aligned}
& \square \text { WT } \\
& \square \text { NBCe1-KO }
\end{aligned}
$$

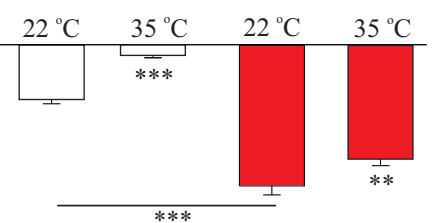

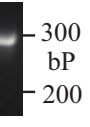

\section{(1)}

$$
\text { Western Blot }
$$

F Staining of cells with NBCe1-AB

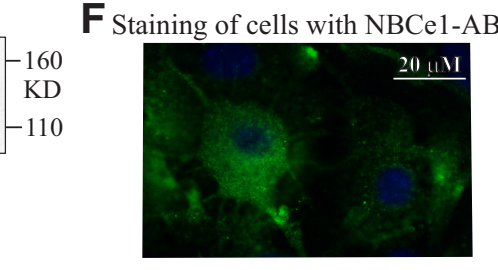

॥N.
Figure 2. Intracellular $\mathrm{H}^{+}$shifts in cultured astrocytes of wild-type and NBCe1-KO mice. $A-C$, Addition and removal of $5 \%$ $\mathrm{CO}_{2} / 26 \mathrm{~mm} \mathrm{HCO}_{3}^{-}$at $22^{\circ} \mathrm{C}$ and $35^{\circ} \mathrm{C}$ resulted in only small $\mathrm{H}^{+}$transients in WT astrocytes $(\boldsymbol{A}, \boldsymbol{B}$, black traces; $\boldsymbol{C}$, open bars), but large $\mathrm{H}^{+}$shifts in NBCe1-KO astrocytes $(\boldsymbol{A}, \boldsymbol{B}$, red traces; $\boldsymbol{C}$, red bars). Both acid and alkaline transients upon addition and removal of frectively, were significantly smaller in cells of WT and $\mathrm{KO}$ mice at higher temperature. $D$, PCR genotyping of DNA Staining of cell culture with Abs against NBCe1 conjugated with Alexa Fluor 488 and Hoechst $(5 \mu \mathrm{g} / \mathrm{ml})$ as cell nuclei marker. Number of cells/cultures/animals as used in the experiments are indicated in or next to the bar plots.

tended to destabilize, and the $\mathrm{pH}$ drifted more and faster after adding $\mathrm{HCO}_{3}^{-}$at low concentration (1-3 mM) without $\mathrm{CO}_{2}$ aeration, presumably due to faster spontaneous conversion of $\mathrm{HCO}_{3}^{-}$to $\mathrm{CO}_{2}$, which would leave the saline solution and cause an alkaline drift of the saline solution. Hence, the actual $\left[\mathrm{HCO}_{3}^{-}\right]$in these experiments may be lower than expected (by $>10 \%$ ). Therefore, only some protocols were performed at $35^{\circ} \mathrm{C}$.

Heterologous expression of NBCe1 and electrophysiology in Xenopus laevis oocytes. Xenopus laevis females were purchased from Xenopus Express. Frogs were anesthetized with $1 \mathrm{~g} / 13$-aminobenzoic acid ethylester (MS-222; Sigma-Aldrich), rendered hypothermic and segments of ovarian lobules were surgically removed under sterile conditions. The procedure was approved by the Landesuntersuchungsamt Rheinland-Pfalz (23 177-07/A07-2-003 \$6) and has been described previously in detail (Becker and Deitmer, 2007). In brief, oocytes were isolated and singularized by collagenase treatment (Collagenase A, Roche) in $\mathrm{Ca}^{2+}$-free oocyte saline solution at $28^{\circ} \mathrm{C}$ for $2 \mathrm{~h}$. The singularized oocytes were left overnight in an incubator at $18^{\circ} \mathrm{C}$ in $\mathrm{Ca}^{2+}$-containing oocyte saline solution, $\mathrm{pH} 7.8$, to recover. The human NBCe1 cDNA was cloned in oocyte expression vector pGH19. Plasmid DNA was linearized with NotI and transcribed in vitro with T7 RNA-polymerase in the presence of the cap analogon $\mathrm{m} 7 \mathrm{G}\left(5^{\prime}\right) \operatorname{ppp}\left(5^{\prime}\right) \mathrm{G}$ (mMessage mMachine, Ambion) to produce a capped RNA transcript. The cRNA was purified with the Qiagen RNeasy MinElute Cleanup Kit and stored at $-80^{\circ} \mathrm{C}$ in diethylpyrocarbonate (DEPC) $-\mathrm{H}_{2} \mathrm{O}$. The oocyte saline solution had the following composition (in mM): $\mathrm{NaCl} 82.5 ; \mathrm{KCl} 2.5 ; \mathrm{CaCl}_{2} 1 ; \mathrm{MgCl}_{2} 1, \mathrm{Na}_{2} \mathrm{HPO}_{4} 1$; HEPES 5, titrated to $\mathrm{pH}$ 7.4. The bicarbonate-containing saline solution contained the following (in $\mathrm{mm}$ ): $\mathrm{NaCl} 58.5 ; \mathrm{KCl} 2.5 ; \mathrm{CaCl}_{2} 1 ; \mathrm{MgCl}_{2} 1$; 

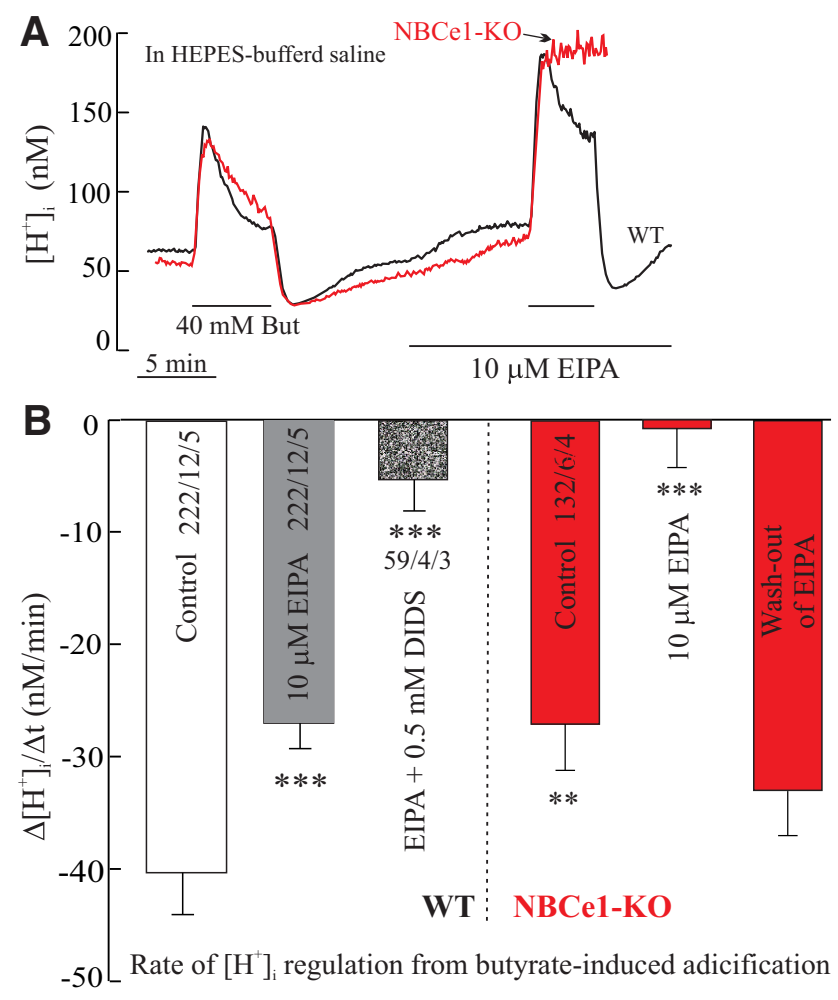

Figure 3. Intracellular $\mathrm{H}^{+}$regulation in nominally $\mathrm{CO}_{2} / \mathrm{HCO}_{3}^{-}$-free saline solution. $A$, Application of $40 \mathrm{~mm}$ butyrate to acidify the cytosol, and the subsequent recovery from acidification with and without EIPA to inhibit $\mathrm{Na}^{+} / \mathrm{H}^{+}$exchange, in WT (black traces) and NBCe1-K0 astrocytes (red traces). $\boldsymbol{B}$, Rate of recovery from intracellular acidification in WT astrocytes with EIPA, or with EIPA and DIDS, and in NBCe1-KO astrocytes treated with EIPA and after washout of EIPA. The number of cells/cultures/animals used in the experiments is indicated in or next to the bar plots.

$\mathrm{Na}_{2} \mathrm{HPO}_{4} 1 ; \mathrm{NaHCO}_{3} 24$, aerated with $5 \% \mathrm{CO}_{2}$ and HEPES 5, to stabilize the $\mathrm{pH}$. Oocytes of the stages $\mathrm{V}$ and VI were selected and injected with $13.8 \mathrm{ng}$ of NBCe1-cRNA dissolved in DEPC- $\mathrm{H}_{2} \mathrm{O}$ using glass micropipettes and a microinjection device (Nanoliter 2000, World Precision Instruments).

For measurement of intracellular $\mathrm{H}^{+}$and membrane potential, double-barreled microelectrodes were used; the manufacture and application have been described in detail previously (Deitmer, 1991). The measurements of $\mathrm{pH}_{\mathrm{i}}$ were stored digitally using custom-made PC software based on the program LabView (National Instruments Germany) and was routinely converted into $\left[\mathrm{H}^{+}\right]_{\mathrm{i}}$. Amplitude and rate of change of the measured $\left[\mathrm{H}^{+}\right]_{\mathrm{i}}$ were analyzed. For voltage-clamp, electrodes filled with $3 \mathrm{M} \mathrm{KCl}$ were connected to the head stages of an Axoclamp 2B amplifier (Molecular Devices). The experimental bath was grounded with a chlorided silver wire coated by agar dissolved in oocyte saline solution. Oocytes were clamped to a holding potential of $-40 \mathrm{mV}$, and all experiments were performed at room temperature $\left(22^{\circ} \mathrm{C}\right)$. For further details see Becker and Deitmer (2007).

Statistical analysis. All statistical analyses were performed using the software SigmaPlot 11.0 and ClampFit 10.2. Statistical values are presented as the mean \pm SEM. For calculation of significance in differences, a Student's $t$ test was used. In the figures shown, significance levels are as follows: ${ }^{*} p \leq 0.05,{ }^{* *} p \leq 0.01$ and ${ }^{* * *} p \leq 0.001$.

\section{Results}

NBCel is a major acid/base regulator in cortical astrocytes

Intracellular $\mathrm{pH}$ was monitored in cultured cortical astrocytes loaded with the $\mathrm{H}^{+}$-selective dye BCECF, calibrated, and converted to $\left[\mathrm{H}^{+}\right]_{\mathrm{i}}$ (Fig. 1; for details, see Materials and Methods). In HEPES-buffered saline solution, $\mathrm{pH} 7.4$, the mean $\left[\mathrm{H}^{+}\right]_{\mathrm{i}}$ values measured in cortical astrocytes from WT and NBCe1-KO mice at room temperature $\left(22^{\circ} \mathrm{C}\right)$ were $67 \pm 1.6 \mathrm{~nm}(n=332)$ and $58 \pm$ $1.8 \mathrm{~nm}(n=242)$, respectively. These values are significantly different $(p<0.01)$, suggesting that at steady state, NBCe1 extrudes net $\mathrm{HCO}_{3}^{-}$. When the bathing solution is switched from a HEPES-buffered, nominally $\mathrm{CO}_{2} / \mathrm{HCO}_{3}^{-}$-free saline solution, to saline solution buffered by $5 \% \mathrm{CO}_{2} / 26 \mathrm{mM} \mathrm{HCO}_{3}^{-}$, changes in $\left[\mathrm{H}^{+}\right]_{\mathrm{i}}$ are attributable primarily to $\mathrm{CO}_{2}$ diffusion across the cell membrane, conversion of $\mathrm{CO}_{2}$ to $\mathrm{H}^{+}$and $\mathrm{HCO}_{3}^{-}$, and subsequent $\left[\mathrm{H}^{+}\right]_{\mathrm{i}}$ regulation. These changes differed greatly in cultured cortical astrocytes from WT or NBCe1-KO mice (Fig. $2 \mathrm{~A}, \mathrm{C})$. The acid $\left[\mathrm{H}^{+}\right]_{\mathrm{i}}$ transient was almost three times as large, while the rate of recovery from acidification was greatly reduced in cells from NBCe1-KO mice compared with WT mice (Fig. 2A). The steady-state $\left[\mathrm{H}^{+}\right]_{\mathrm{i}}$ in saline solution buffered with $5 \% \mathrm{CO}_{2} /$ $26 \mathrm{mM} \mathrm{HCO}_{3}^{-}$was $63 \pm 2.3 \mathrm{nM}(n=253)$ in WT astrocytes and $62 \pm 2 \mathrm{nM}(n=280)$ in astrocytes from NBCe1-KO mice. These values are not significantly different from each other and from those measured in HEPES-buffered saline solution. From the average $\left[\mathrm{H}^{+}\right]_{\mathrm{i}}$ in $\mathrm{CO}_{2} / \mathrm{HCO}_{3}^{-}$-buffered saline solution, a mean intracellular $\mathrm{HCO}_{3}^{-}$concentration of $14.7 \mathrm{~mm}$ was calculated in astrocytes from WT mice and $14.9 \mathrm{~mm}$ in astrocytes from NBCe1-KO mice. From these values and the extracellular $\left[\mathrm{HCO}_{3}^{-}\right]$of $26 \mathrm{mM}, \mathrm{H}^{+} / \mathrm{HCO}_{3}^{-}$equilibrium potentials of -14.5 and $-14.1 \mathrm{mV}$ in $\mathrm{WT}$ and $\mathrm{NBCe} 1-\mathrm{KO}$, respectively, is obtained by the Nernst equation.

When the experimental temperature was raised to $35^{\circ} \mathrm{C}$, the mean $\left[\mathrm{H}^{+}\right]_{\mathrm{i}}$ in cortical astrocytes from WT and NBCe1-KO mice was $66 \pm 3.0 \mathrm{nM}(n=51)$ and $75 \pm 3.4 \mathrm{nM}(n=54)$, respectively. The value for $\mathrm{NBCe} 1-\mathrm{KO}$ mice at $35^{\circ} \mathrm{C}$ was significantly greater than that at $22^{\circ} \mathrm{C}$ and was also greater than that measured in WT cells at $35^{\circ} \mathrm{C}$ (both $p<0.001$ ), while the $\left[\mathrm{HCO}_{3}^{-}\right]$was calculated to be $10.5 \mathrm{~mm}$ in astrocytes at $35^{\circ} \mathrm{C}$ in $\mathrm{NBCe} 1-\mathrm{KO}$ mice. Changing from HEPES-buffered, nominally $\mathrm{CO}_{2} / \mathrm{HCO}_{3}^{-}$-free saline solution, to saline solution buffered by $5 \% \mathrm{CO}_{2} / 21 \mathrm{mM} \mathrm{HCO}_{3}^{-}$at $35^{\circ} \mathrm{C}$ induced a very small, brief acidification followed by a partially transient $\left[\mathrm{H}^{+}\right]_{\mathrm{i}}$ shift by approximately $-10 \mathrm{nM}$ in cells from WT mice, while a robust acidification was recorded in cells from NBCe1-KO mice, followed by a recovery (Fig. $2 B, C$ ). From the rate of alkalinization, which followed the acidification upon addition of $5 \% \mathrm{CO}_{2} / 26 \mathrm{~mm} \mathrm{HCO}_{3}^{-}$, at $22^{\circ} \mathrm{C}$ and $35^{\circ} \mathrm{C}$ (Fig. $2 \mathrm{~A}, \mathrm{~B}$ ), a $\mathrm{Q}_{10}$ temperature coefficient of 1.8 was calculated. The transient alkalinization upon removal of $\mathrm{CO}_{2} / \mathrm{HCO}_{3}^{-}$was smaller and faster in cells from WT mice compared with those from NBCe1-KO mice (Fig. 2A-C).

In these and other studies described below, genotyping of DNA from NBCe1-KO mice revealed only the smaller PCR product characteristic of the null allele; in WT mice, only the larger PCR product characteristic of the WT allele was observed, and bands for both alleles were observed in heterozygous mice (Fig. $2 D)$. Accordingly, no expression of NBCe1 protein was detected in astrocytes of homozygous NBCe1-KO mice, in contrast to WT mice, as revealed by Western blotting (Fig. 2E). Antibody directed against $\mathrm{NBCe} 1$ showed intense staining of the cultured cortical astrocytes from WT mice (Fig. $2 F$ ).

We used butyric acid (40 mM butyrate) in HEPES-buffered saline solution, with a constant $\mathrm{pH}$ of 7.4, as another method for acidifying the cytosol. Butyric acid was chosen as the weak acid to acidify the cells, because the $\left[\mathrm{H}^{+}\right]_{\mathrm{i}}$ completely returned to its initial value after removal of butyric acid after inhibiting $\mathrm{H}_{\mathrm{i}}^{+}$ regulation (in the absence of $\mathrm{CO}_{2} / \mathrm{HCO}_{3}^{-}$and in the presence of EIPA; Fig. $4 A, C$; see also Fig. $8 A, B$ ), indicating that there was little or no metabolic consumption of butyrate by the cells during 
the exposure of butyric acid for 5-30 min. In addition, the uptake of butyric acid in Xenopus oocytes was the same when oocytes were injected with cRNA for monocarboxylate transporter 1 (MCT1) or water, indicating that the contribution of MCT1-mediated transport of butyric acid into oocytes was insignificant, and the uptake of butyrate occurred as undissociated acid (Bröer et al., 1998).

Blocking sodium/hydrogen exchange (NHE) with EIPA $(10 \mu \mathrm{M})$ in HEPESbuffered, nominally $\mathrm{CO}_{2} / \mathrm{HCO}_{3}^{-}$-free saline solution considerably slowed $\left[\mathrm{H}^{+}\right]_{\mathrm{i}}$ regulation in WT cells and reversibly suppressed $\left[\mathrm{H}^{+}\right]_{\mathrm{i}}$ regulation in NBCe1-KO mouse astrocytes (Fig. $3 A, B$ ). In WT astrocytes, the rate of $\mathrm{H}^{+}{ }_{i}$ recovery was reduced to $67 \%$ by EIPA, while the anion transport antagonist DIDS (0.5 mM), applied together with EIPA, reduced this rate of recovery to $\sim 10 \%$ of the control. These results suggest that (1) NHE and NBCe1 both make major contributions to $\left[\mathrm{H}^{+}\right]_{\mathrm{i}}$ regulation, and (2) after blocking NHE, NBCel can still sustain robust $\left[\mathrm{H}^{+}\right]_{\mathrm{i}}$ regulation even in the nominal absence of $\mathrm{CO}_{2} / \mathrm{HCO}_{3}^{-}$in cortical astrocytes.

\section{The significance of residual bicarbonate in nominally $\mathrm{CO}_{2} / \mathrm{HCO}_{3}^{-}$-free saline solution for $\left[\mathrm{H}^{+}\right]_{\mathbf{i}}$}

Our experiments showed that $\mathrm{NBCe} 1$ activity is maintained even in the nominal absence of $\mathrm{CO}_{2} / \mathrm{HCO}_{3}^{-}$in HEPES-buffered saline solution, suggesting that residual $\mathrm{HCO}_{3}^{-}$in the saline solution, derived from equilibration of air $\mathrm{CO}_{2}$ and calculated to be $\sim 150-$ $200 \mu \mathrm{M}$ at pH 7.4, is sufficient to maintain NBCe1 activity. We tested this hypothesis by aerating HEPES-buffered saline solution with $100 \% \mathrm{O}_{2}$ to displace $\mathrm{CO}_{2}$ from the saline solution and hence reduce the $\left[\mathrm{HCO}_{3}^{-}\right]$further. In this solution $\left(\mathrm{HEPES}-\mathrm{O}_{2}\right)$, EIPA reversibly reduced $\left[\mathrm{H}^{+}\right]_{\mathrm{i}}$ regulation by $>90 \%$ in WT astrocytes when they were challenged by application of $40 \mathrm{~mm}$ butyrate. Subsequent removal of $\mathrm{O}_{2}$ aeration accelerated $\left[\mathrm{H}^{+}\right]_{\mathrm{i}}$ regulation substantially (Fig. 4A,B).

A similar experiment in acute cortical brain slices from mice showed that in astrocytes, $\left[\mathrm{H}^{+}\right]_{\mathrm{i}}$ recovery from a $40 \mathrm{~mm}$ butyrateinduced acidification was reduced, but was not abolished, by EIPA in HEPES-buffered, nominally $\mathrm{CO}_{2} / \mathrm{HCO}_{3}^{-}$-free saline solution, but completely suppressed when the saline solution was aerated with $\mathrm{O}_{2}$ (Fig. 4C,D). In acute slices of NBCe1-KO mice, $\left[\mathrm{H}^{+}\right]_{\mathrm{i}}$ regulation was fully blocked by EIPA alone. Similar results were obtained in slices from $\mathrm{mRFP} / \mathrm{NBC}-\mathrm{KO}$ mice. These results strongly suggest that residual bicarbonate in nominally $\mathrm{CO}_{2}$ / $\mathrm{HCO}_{3}^{-}$-free saline solution is sufficient to maintain significant NBCel activity and hence $\left[\mathrm{H}^{+}\right]_{\mathrm{i}}$ regulation in cortical astrocytes in vitro and in situ, as measured in the presence of EIPA to block NHE.

\section{Membrane potential-dependent activation of NBCe1}

Since NBCe1 is electrogenic, it can be activated by changes in the membrane potential (Deitmer and Szatkowski, 1990; Brookes and Turner, 1994). To confirm the molecular identity responsi-

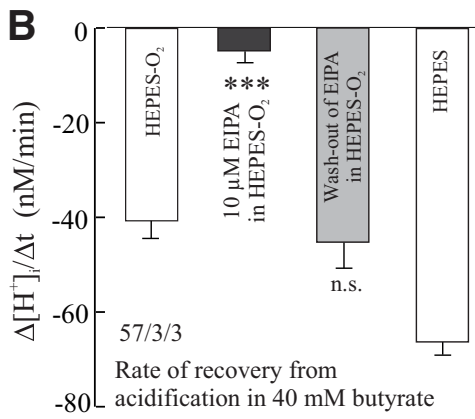

$-80 \mathrm{~L}$ acidification in $40 \mathrm{mM}$ butyrate

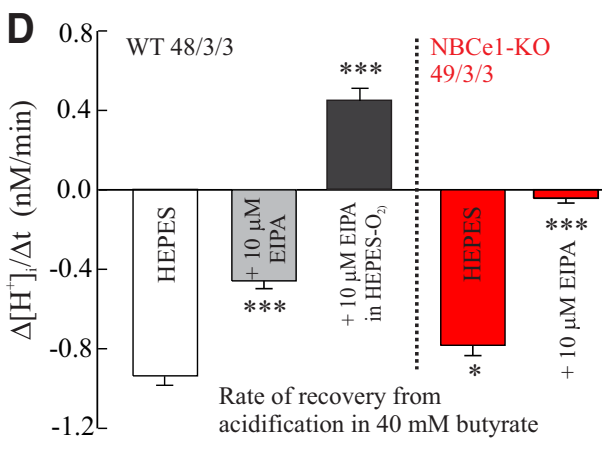

acidification in $40 \mathrm{mM}$ butyrate

Figure 4. Intracellular $\mathrm{H}^{+}$regulation is still maintained by residual bicarbonate in nominally $\mathrm{CO}_{2} / \mathrm{HCO}_{3}^{-}$-free saline solution. $A$, different solutions in WT (open, gray and black bars) and in NBCe1-KO (red bars) mice (D). The number of cells/cultures/animals used in the experiments is indicated in $\boldsymbol{B}$ and $\boldsymbol{D}$.

ble for the bicarbonate-dependent $\left[\mathrm{H}^{+}\right]_{\mathrm{i}}$ regulation, cultured cortical astrocytes were depolarized by elevating the external $\mathrm{K}^{+}$ concentration from 5 to $15 \mathrm{~mm}$ (Fig. 5). In WT astrocytes, $15 \mathrm{~mm}$ $\mathrm{K}^{+}$elicited a fall in $\left[\mathrm{H}^{+}\right]_{\mathrm{i}}$ in HEPES-buffered saline solution; this fall was augmented in $\mathrm{CO}_{2} / \mathrm{HCO}_{3}^{-}$-buffered saline solution, and decreased in HEPES-O $\mathrm{O}_{2}$ saline solution with EZA $(10 \mu \mathrm{M})$, which was added to lower the effective $\left[\mathrm{HCO}_{3}^{-}\right]$, both in amplitude and rate (Fig. $5 A, C, D$ ). In astrocytes from NBCe1-KO mice, $15 \mathrm{mM} \mathrm{K}^{+}$elicited a small rise in $\left[\mathrm{H}^{+}\right]_{\mathrm{i}}$ both in HEPESbuffered and in $\mathrm{CO}_{2} / \mathrm{HCO}_{3}^{-}$-buffered saline solution (Fig. $5 \mathrm{~B}-$ $D)$. These results indicate that (1) the intracellular alkalinization in $15 \mathrm{~mm} \mathrm{~K}^{+}$observed in WT cells was due to activation of $\mathrm{NBCe} 1$; (2) the high $\mathrm{K}^{+}$-dependent alkalinization was still robust in HEPES-buffered, nominally $\mathrm{CO}_{2} /$ $\mathrm{HCO}_{3}^{-}$-free saline solution; and (3) lowering the $\left[\mathrm{HCO}_{3}^{-}\right]$by $\mathrm{O}_{2}$ aeration in HEPES-buffered, nominally $\mathrm{CO}_{2} / \mathrm{HCO}_{3}^{-}$-free saline solution reduced the amplitude and rate of alkalinization, as predicted by experiments shown in Figure 4.

\section{Cortical astrocytes respond to low bicarbonate concentrations}

The high sensitivity for bicarbonate in cortical astrocytes that appeared to be due to NBCe1 was further studied by adding low concentrations of bicarbonate to a HEPES-buffered saline solution aerated with $100 \% \mathrm{O}_{2}$ (Fig. 6). Exposing the cells to $3 \mathrm{~mm}, 1$ $\mathrm{mM}$, and $0.3 \mathrm{mM} \mathrm{HCO}_{3}^{-}$evoked a concentration-dependent fall of the $\left[\mathrm{H}^{+}\right]_{\mathrm{i}}$ in astrocytes of WT mice (Fig. $6 A, B$ ). In cells from NBCe1-KO mice, a rise of $10-20 \mathrm{nM}\left[\mathrm{H}^{+}\right]_{\mathrm{i}}$ was observed at $3 \mathrm{~mm}$ $\left[\mathrm{HCO}_{3}^{-}\right]$(Fig. $6 \mathrm{~A}$, red trace), presumably due to diffusion of $\mathrm{CO}_{2}$ formed from the added $\mathrm{HCO}_{3}^{-}$. It should be noted here that 

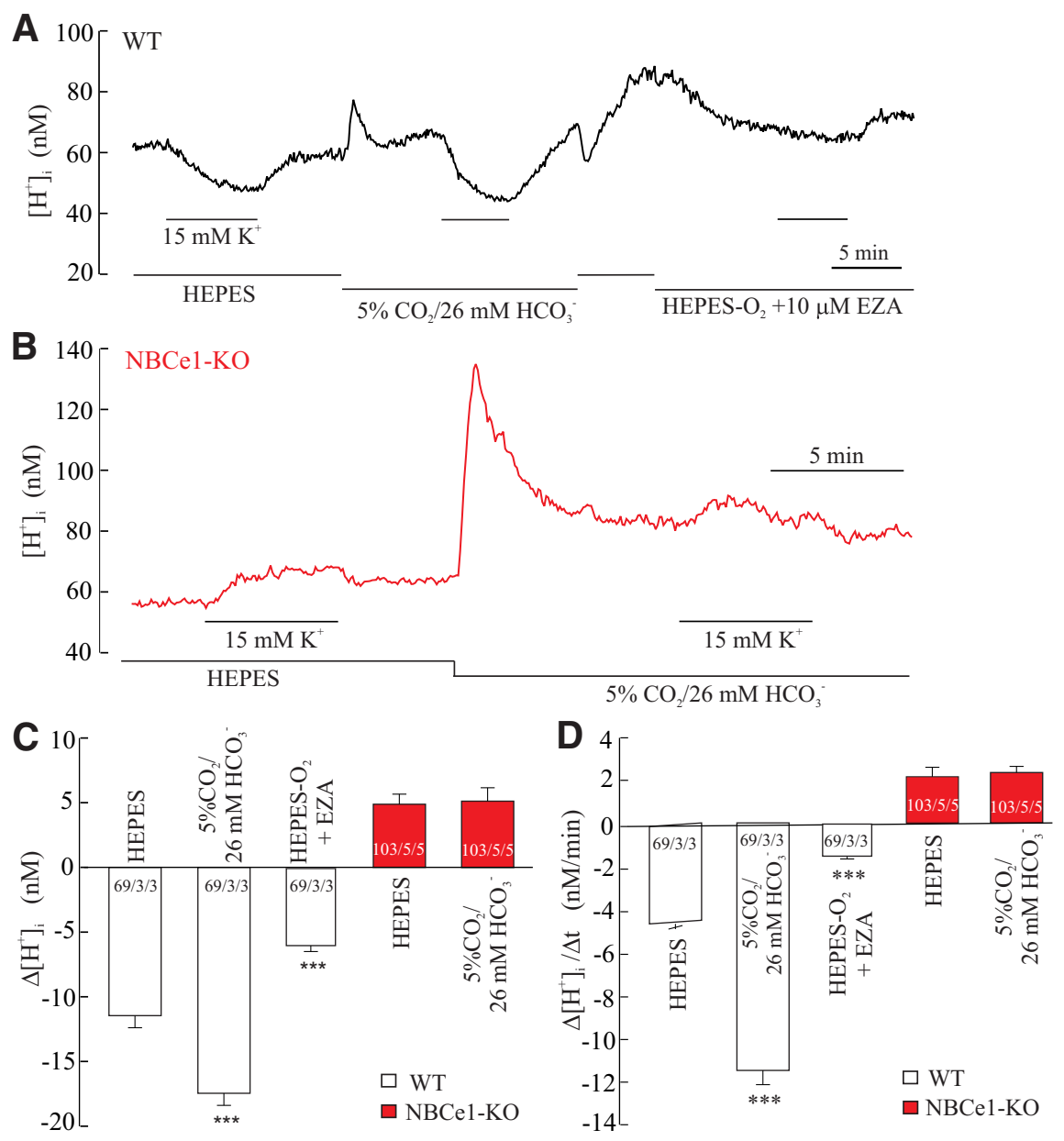

Figure 5. Membrane potential-dependent changes in intracellular $\mathrm{H}^{+}$concentration in saline solution with different potassium concentrations. $\boldsymbol{A}, \boldsymbol{B}$, Intracellular $\mathrm{H}^{+}$changes in WT $(\boldsymbol{A})$ and in NBCe1-KO $(\boldsymbol{B})$ cortical astrocytes during exposure to $15 \mathrm{~mm}$ $\mathrm{K}^{+}$(from normal $5 \mathrm{~mm} \mathrm{~K}^{+}$) in a HEPES-buffered, nominally $\mathrm{CO}_{2} / \mathrm{HCO}_{3}^{-}$-free saline solution, in a $5 \% \mathrm{CO}_{2} / 26 \mathrm{~mm} \mathrm{HCO}-$-buffered saline solution, and in a HEPES- $\mathrm{O}_{2}$ saline solution containing EZA (10 $\left.\mu \mathrm{m}\right)$ to block carbonic anhydrase activity (only in $\left.\boldsymbol{A}\right)$. C, D, Changes in the intracellular $\left[\mathrm{H}^{+}\right](\boldsymbol{C})$ and the rate of $\left[\mathrm{H}^{+}\right]_{\mathrm{i}}$ changes $(\boldsymbol{D})$ in the different saline solutions, in WT (open bars) and NBC 1-KO (red bars) astrocytes. The number of cells/cultures/animals used in the experiments is indicated in the bars.

adding $\mathrm{HCO}_{3}^{-}$to a solution not aerated with $\mathrm{CO}_{2}$, will lead to continuous loss of $\mathrm{HCO}_{3}^{-}$from the saline solution as $\mathrm{CO}_{2}$, while the saline solution $\mathrm{pH}$ would accordingly rise. From this rise in saline solution $\mathrm{pH}$, we calculated that the loss of $\mathrm{HCO}_{3}^{-}$might be up to $10 \%$ at $22^{\circ} \mathrm{C}$, within the duration of our experiments of 15-30 min. Therefore, the effective $\mathrm{HCO}_{3}^{-}$concentration would be lower than the amount added at the beginning of the experiments (e.g., at $22^{\circ} \mathrm{C}$ by up to $0.1 \mathrm{~mm}$ when $1 \mathrm{~mm} \mathrm{HCO}_{3}^{-}$was added, and up to $0.3 \mathrm{~mm}$, when $3 \mathrm{mM} \mathrm{HCO}_{3}^{-}$was added). In addition, some of the $\mathrm{CO}_{2}$ formed from the added $\mathrm{HCO}_{3}^{-}$would diffuse into the cells and acidify the cytosol, as observed in cells of NBCe1-KO mice (see above), and would counteract the NBCe1mediated alkalinization in WT cells. To minimize the loss of added $\mathrm{HCO}_{3}^{-}$from these saline solutions, the low $\left[\mathrm{HCO}_{3}^{-}\right]$solutions were always freshly prepared within 3-6 min before use.

When acute cortical slices were used, the $\left[\mathrm{H}^{+}\right]_{\mathrm{i}}$ responded with a small decrease in WT astrocytes in situ and a small increase in NBCe1-KO astrocytes, when 1 and $3 \mathrm{mM} \mathrm{HCO}_{3}^{-}$was added to the bathing solution at $35^{\circ} \mathrm{C}$ (Fig. $6 C, D$ ). Changing from a HEPES-buffered, $\mathrm{O}_{2}$-aerated saline solution, to a saline solution buffered by $5 \% \mathrm{CO}_{2} / 21 \mathrm{mM} \mathrm{HCO}_{3}^{-}$at $35^{\circ} \mathrm{C}, \mathrm{pH} 7.4$, induced a small, brief acidification followed by a $\left[\mathrm{H}^{+}\right]_{\mathrm{i}}$ shift by $5-10 \mathrm{~nm}$ in cells from WT mice, while a robust acidification was recorded in cells from NBCe1-KO mice, followed by a recovery (Fig. 6C,D), similar to that described for cultured cortical astrocytes (Fig. 2B,C). A direct comparison of NBCel transport activity at $22^{\circ} \mathrm{C}$ and $35^{\circ} \mathrm{C}$ in the same cells turned out to be difficult in situ, as the cells in the slice preparation appeared to lose viability during the rapid $\left(\sim 1^{\circ} \mathrm{C} / \mathrm{min}\right)$ warming process.

\section{Activation by low $\left[\mathrm{HCO}_{3}^{-}\right]$of human NBCe1 heterologously expressed in Xenopus oocytes}

To estimate the sensitivity of NBCe1 activity to HEPES-buffered saline solution with and without $\mathrm{O}_{2}$ aeration, we heterologously expressed human NBCe1 in $\mathrm{Xe}$ nopus oocytes (Becker and Deitmer, 2007) and recorded the membrane current during intracellular acidification induced by $20 \mathrm{~mm}$ butyrate in HEPES-buffered saline solution in the nominal absence of $\mathrm{CO}_{2} /$ $\mathrm{HCO}_{3}^{-}$(Fig. $7 A, B$ ). The NBCe1 current was reduced by $\sim 50 \%$ in HEPES-O $\mathrm{O}_{2}$ saline solution, while in native oocytes no current change was recorded in $20 \mathrm{~mm}$ butyrate, suggesting that there is a substantial reduction of NBCel activity during $\mathrm{O}_{2}$ aeration.

To confirm that NBCe1 could be responsible for the $\left[\mathrm{H}^{+}\right]_{\mathrm{i}}$ fall evoked by low extracellular $\left[\mathrm{HCO}_{3}^{-}\right]$, human $\mathrm{NBCe} 1$ was expressed in Xenopus oocytes and exposed to low $\left[\mathrm{HCO}_{3}^{-}\right]$in HEPESbuffered, nominal $\mathrm{CO}_{2} / \mathrm{HCO}_{3}^{-}$-free saline solution. The addition of 1 and $3 \mathrm{~mm}$ $\left[\mathrm{HCO}_{3}^{-}\right]$evoked a fall in $\left[\mathrm{H}^{+}\right]_{\mathrm{i}}$ (Fig. $7 C, D)$ and a robust outward current (Fig. $7 D, E)$ in NBCe1-expressing oocytes, while in native oocytes a slow rise in $\left[\mathrm{H}^{+}\right]_{\mathrm{i}}$ and no membrane current was observed (Fig. $7 C-E$ ), even when $5 \% \mathrm{CO}_{2} / 25 \mathrm{~mm}$ $\mathrm{HCO}_{3}^{-}$was added (Fig. $7 E$ ). The rate of $\left[\mathrm{H}^{+}\right]_{\mathrm{i}}$ fall and the outward current in NBCe1-expressing oocytes show that NBCe1 can be activated by low-millimolar $\left[\mathrm{HCO}_{3}^{-}\right]$. Again, the effective concentrations of $\mathrm{HCO}_{3}^{-}$would be somewhat lower than the amount added, as stated above.

\section{Determination of NBCe1 transport activity at different $\left[\mathrm{HCO}_{3}^{-}\right]$and $\left[\mathrm{H}^{+}\right]_{\mathrm{i}}$}

To challenge NBCe1 activity by acidifying the cytosol, we exposed cultured astrocytes to $40 \mathrm{~mm}$ butyrate in HEPES-buffered saline solution aerated with $\mathrm{O}_{2}$ and with EIPA to block NHE. This increased $\left[\mathrm{H}^{+}\right]_{\mathrm{i}}$ from 20 to $90 \mathrm{~nm}$ up to $>100 \mathrm{~nm}$ with the saline solution $\mathrm{pH}$ set at constant $\mathrm{pH} 7.4$ (Fig. $8 A, B, D$ ). Under these conditions, the addition of a low $\left[\mathrm{HCO}_{3}^{-}\right]$between 0.1 and $3 \mathrm{~mm}$ evoked a concentration-dependent fall of the $\left[\mathrm{H}^{+}\right]_{\mathrm{i}}$ in astrocytes from WT mice (Fig. $8 A, C$ ). In contrast, in cells from NBCe1-KO mice, the low $\left[\mathrm{HCO}_{3}^{-}\right]$elicited a slow acidification, which only turned into a moderate alkalinization at $3 \mathrm{~mm} \mathrm{HCO}_{3}^{-}$(Fig. $8 \mathrm{~B}, \mathrm{C})$. The rate of fall in $\left[\mathrm{H}^{+}\right]_{\mathrm{i}}$ in WT cells showed a dependence on the $\left[\mathrm{HCO}_{3}^{-}\right]$with a $K_{\mathrm{m}}$ of $0.65 \mathrm{mM}$, as calculated from the fit through the data points (Fig. $8 C$, control). Removal of external 

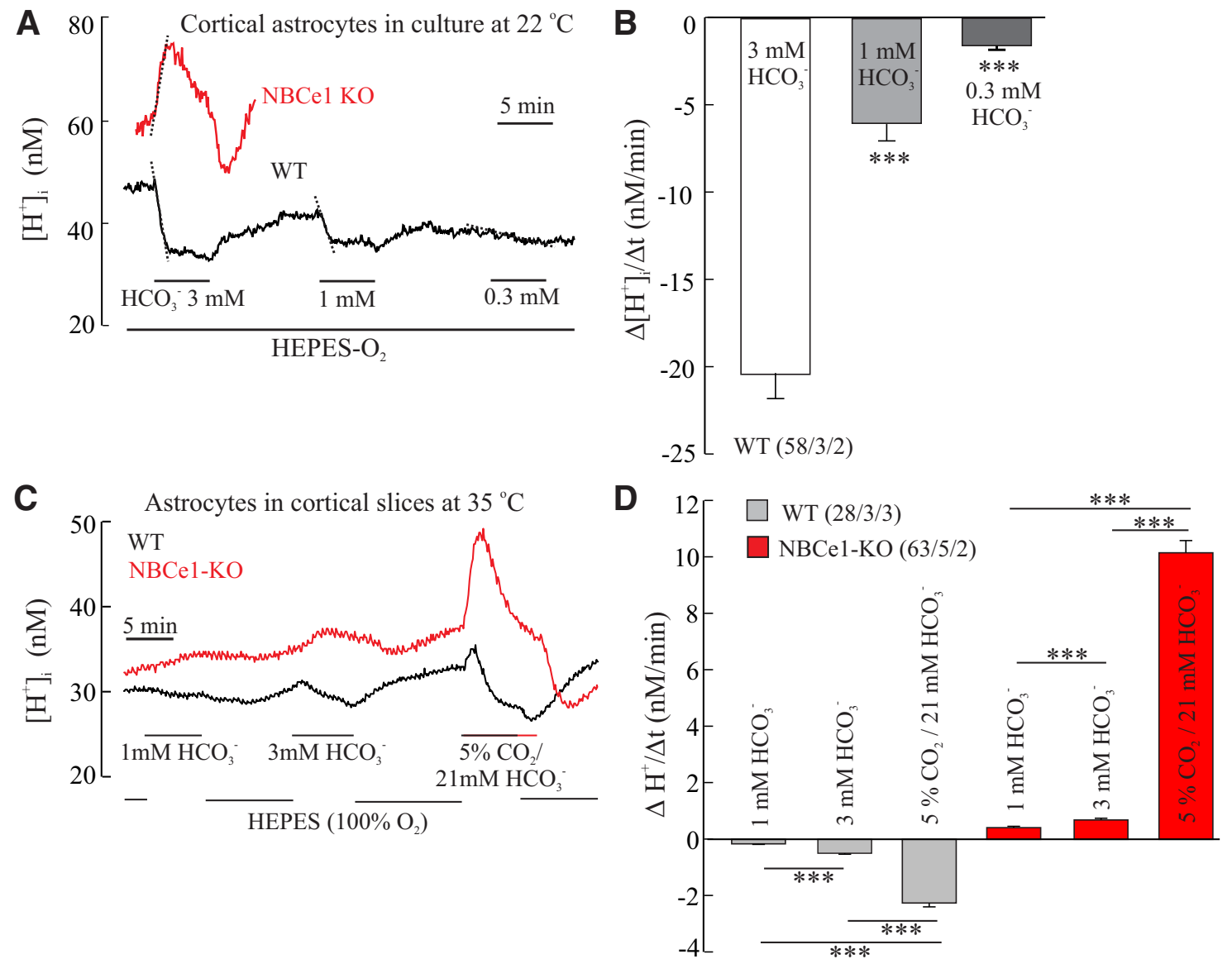

Figure 6. Bicarbonate sensitivity of wild-type and NBCe1-KO astrocytes. $A-D$, Changes in intracellular $\left[\mathrm{H}^{+}\right]$of cultured astrocytes $(A, B)$ during the addition of low concentrations of $\mathrm{HCO}_{3}^{-}$in HEPES- $0_{2}$ saline solution in cells of WT ( $\boldsymbol{A}$, black trace) and of NBC-KO (A, red trace) mice at $22^{\circ} \mathrm{C}$ and corresponding rates of $\left[\mathrm{H}^{+}\right]_{i}$ changes $(\boldsymbol{A}$, dotted lines) in WT cells $(\boldsymbol{B})$. Changes in intracellular $\left[\mathrm{H}^{+}\right]$in astrocytes of acute cortical slices $(\boldsymbol{C}, \boldsymbol{D})$ during the addition of low concentrations of $\mathrm{HCO}_{3}^{-}$in HEPES- $0_{2}$ saline solution in cells of WT (C, black trace) and NBC-KO (C, red trace) mice at $35^{\circ} \mathrm{C}$, and corresponding rates of $\left[\mathrm{H}^{+}\right]_{\mathrm{i}}$ changes $(\boldsymbol{D})$.

chloride (replaced by gluconate) had little effect on the rate of bicarbonate-dependent $\left[\mathrm{H}^{+}\right]_{\mathrm{i}}$ fall, while in the presence of EZA $(10 \mu \mathrm{M})$, an effective inhibitor of carbonic anhydrase activity, this rate was reduced by $>70 \%$, both in the presence and absence of external chloride ( $K_{\mathrm{m}}$ values $0.54 \mathrm{~mm}$ in EZA, and $1 \mathrm{~mm}$ in EZA/0 $\mathrm{Cl}^{-}$, as calculated from the fits through the data). Due to loss of some $\mathrm{HCO}_{3}^{-}$from these $\mathrm{O}_{2}$-aerated saline solutions (see above), the $K_{\mathrm{m}}$ values would likely be even lower. These experiments also suggest that at very low extracellular $\mathrm{CO}_{2} / \mathrm{HCO}_{3}^{-}$concentrations, rapid conversion of $\mathrm{CO}_{2}$ to and from $\mathrm{HCO}_{3}^{-}$, catalyzed by carbonic anhydrase activity, is essential to maintain the effective $\left[\mathrm{HCO}_{3}^{-}\right]$and hence $\mathrm{HCO}_{3}^{-}$transport via $\mathrm{NBCe} 1$, while the absence of chloride makes little difference to the rate of bicarbonatedependent $\left[\mathrm{H}^{+}\right]_{\mathrm{i}}$ fall.

The rate of bicarbonate-dependent fall in $\left[\mathrm{H}^{+}\right]_{\mathrm{i}}$ was also plotted versus the initial, steady-state $\left[\mathrm{H}^{+}\right]_{\mathrm{i}}$, as measured just before adding bicarbonate, from experiments as shown in Figures $6 \mathrm{~A}$ and $8, A$ and $D$. There was only a small dependence of this rate at an initial concentration of $<100 \mathrm{nM}\left[\mathrm{H}^{+}\right]_{\mathrm{i}}$, and the linear fit had a slope of $36.9 \pm 16.5 \mathrm{~min}^{-1}$; however, at an initial $\left[\mathrm{H}^{+}\right]_{\mathrm{i}}$ of $>100 \mathrm{nM}$, as achieved in the presence of $40 \mathrm{~mm}$ butyrate, this dependence was robust. Between 200 and $800 \mathrm{~nm}\left[\mathrm{H}^{+}\right]_{\mathrm{i}}, \mathrm{pH}_{\mathrm{i}}$ $6.7-6.1$, the linear fits had slopes of $142.8 \pm 9.6$ and $384 \pm 59.5$ min ${ }^{-1}$, respectively, in $0.3 \mathrm{mM} \mathrm{HCO}_{3}^{-}$and $3 \mathrm{mM} \mathrm{HCO}_{3}^{-}(p<$ $0.0001)$. These results show that the rate of $\left[\mathrm{H}^{+}\right]_{\mathrm{i}}$ change was dependent on the extracellular $\left[\mathrm{HCO}_{3}^{-}\right]$and the intracellular $\left[\mathrm{H}^{+}\right]$.

\section{Discussion}

Using WT and NBCe1-deficient mice, we have shown that the electrogenic sodium bicarbonate cotransporter is an apparently high-affinity bicarbonate transporter in mouse cortical astrocytes. NBCel can be activated by submillimolar $\left[\mathrm{HCO}_{3}^{-}\right]$during moderate or severe acidosis, and is hence - to our knowledge - the bicarbonate transporter/protein with the highest apparent sensitivity for bicarbonate that has been described so far. As a consequence of its high bicarbonate sensitivity, NBCe1 may function as a sensor for low bicarbonate concentrations, such as those that occur during severe acidosis. The NBCel activity and bicarbonate sensitivity were even increased at a physiological temperature of $35^{\circ} \mathrm{C}$ compared with room temperature. We show that $\mathrm{NBCe} 1$ in cortical astrocytes and in cRNA-injected frog oocytes transports a significant amount of substrate even in nominally $\mathrm{CO}_{2} / \mathrm{HCO}_{3}^{-}$free saline solution (i.e., with no $\mathrm{CO}_{2} / \mathrm{HCO}_{3}^{-}$added), which contain $\sim 150-200 \mu \mathrm{M} \mathrm{HCO}_{3}^{-}$due to air $\mathrm{CO}_{2}$ equilibrated in saline solutions. The results are significant because (1) bicarbonate can still be transported across the cell membrane, even if the $\left[\mathrm{HCO}_{3}^{-}\right]$ on either side of the membrane is low; (2) saline solutions, nominally free of $\mathrm{CO}_{2} / \mathrm{HCO}_{3}^{-}$, as has been used in numerous physiological and biochemical experiments, and is assumed to be 
A
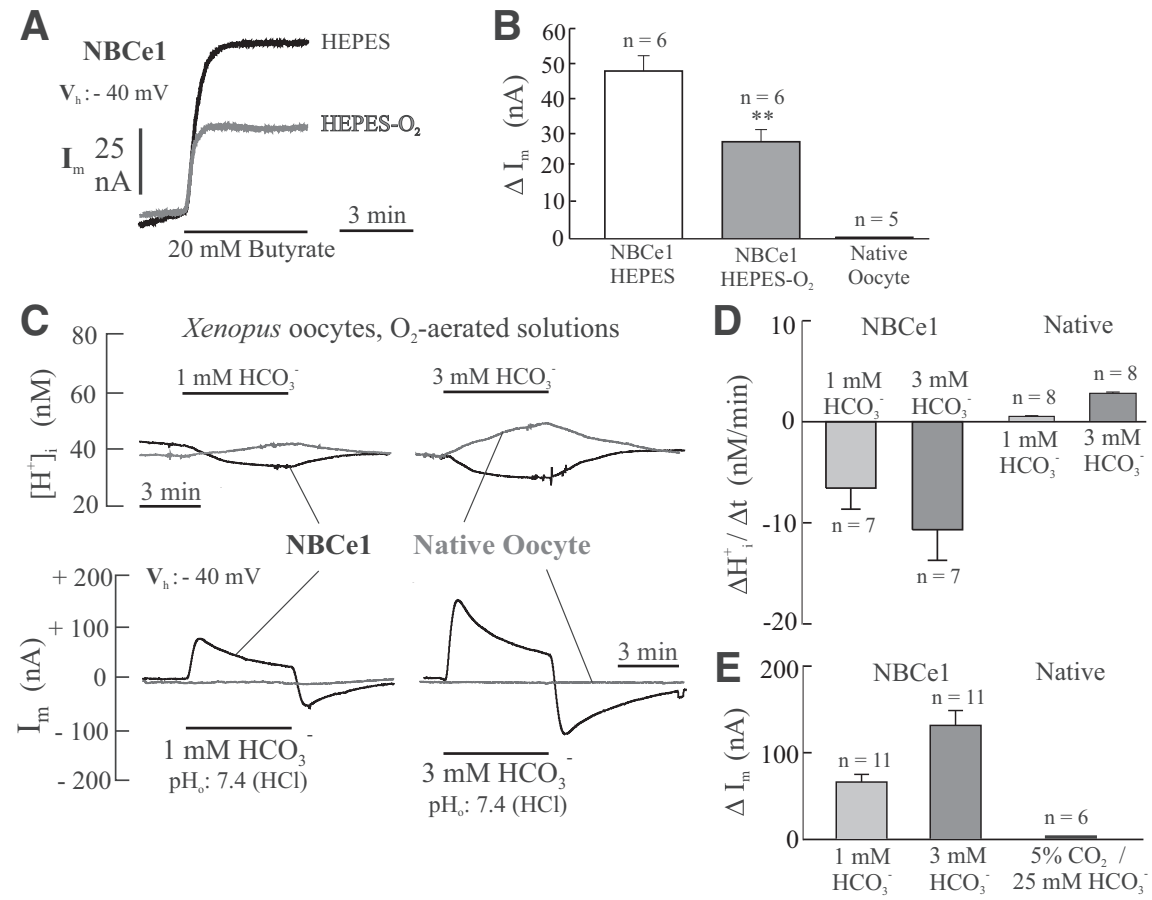

Figure 7. Characteristics of human NBCe1 heterologously expressed in Xenopus oocytes. $\boldsymbol{A}, \boldsymbol{B}$, Membrane current in NBCe1expressing Xenopus oocytes in $\mathrm{HEPES}$-buffered, nominally $\mathrm{CO}_{2} / \mathrm{HCO}_{3}^{-}$-free saline solution, challenged by intracellular acidification induced by exposure to $20 \mathrm{~mm}$ butyric acid, with and without $100 \% \mathrm{O}_{2}$ aeration (i.e., HEPES- $\mathrm{O}_{2}$ ). Lowering residual bicarbonate by $\mathrm{O}_{2}$ aeration reduced this membrane current significantly $(p<0.01, n=6)$. $\boldsymbol{C}, \boldsymbol{D}$, Changes in the intracellular $\left[\mathrm{H}^{+}\right]_{\mathrm{i}}(\boldsymbol{C}$, upper traces) and in the membrane current $I_{\mathrm{m}}(\boldsymbol{C}$, lower traces, $\boldsymbol{E})$, and plot of the rate of $\left[\mathrm{H}^{+}\right]_{\mathrm{i}}$ change $(\boldsymbol{D})$ in NBCe1-expressing and native oocytes to show that $\mathrm{NBCe} 1$ is activated by low extracellular $\left[\mathrm{HCO}_{3}^{-}\right]$in this heterologous expression system. The number of experiments is indicated above or below the bar plots in $\boldsymbol{B}, \boldsymbol{D}$, and $\boldsymbol{E}$.

$\mathrm{HCO}_{3}^{-}$-free, may contain enough bicarbonate $(150-200 \mu \mathrm{M})$ to activate or maintain significant transport; and (3) NBCe1 has been identified as an apparently high-affinity bicarbonate transporter in cortical astrocytes.

\section{NBCel is activated by low bicarbonate concentrations in both astrocytes and oocytes}

The following evidence indicates that the apparently high bicarbonate transport sensitivity is mediated by NBCe1: (1) the activity was greatly reduced or absent in cultured cells, and acute tissue slices were obtained from NBCe1-KO mice; (2) an intracellular alkalinization could be elicited by high- $\mathrm{K}^{+}$saline solution in WT astrocytes, consistent with previously demonstrated depolarization-induced bicarbonate inward transport (Deitmer and Szatkowski, 1990; Brookes and Turner, 1994; Pappas and Ransom, 1994), but not in astrocytes from NBCe1-KO mice (see also Svichar et al., 2011); (3) reduction of the residual $\left[\mathrm{HCO}_{3}^{-}\right]$by $\mathrm{O}_{2}$ aeration of the saline solution suppressed both alkalinization in high- $\mathrm{K}^{+}$ saline solutions and intracellular $\mathrm{H}^{+}$regulation following acidification with concurrent NHE inhibition; and (4) NBCel heterologously expressed in Xenopus oocytes was shown to be activated by the residual $\left[\mathrm{HCO}_{3}^{-}\right]$in HEPES-buffered, nominally $\mathrm{CO}_{2} / \mathrm{HCO}_{3}^{-}$-free saline solution, and by the addition of 1 and 3 mM $\mathrm{HCO}_{3}^{-}$.

A high bicarbonate sensitivity of the NBC in glial cells had previously been suggested for cerebral astrocytes (Brookes and Turner, 1994) and for leech neuropil glial cells (Deitmer and Schneider, 1998). In both studies, residual $\mathrm{CO}_{2} / \mathrm{HCO}_{3}^{-}$was shown to maintain NBC activity, which was stimulated by raising the extracellular $\left[\mathrm{K}^{+}\right]$, although the precise molecular identity of the NBC could not be presented then (the first mammalian NBC cloned was reported by Romero et al., 1998). We postulate that the NBCe1 in cortical astrocytes, and possibly in astrocytes of other brain regions and in other cell types, might be a sensor for low $\left[\mathrm{HCO}_{3}^{-}\right]$.

\section{The significance of NBCel for $\mathrm{H}^{+}$regulation}

There are multiple processes in the nervous system, which are critically dependent upon extracellular and intracellular $\mathrm{pH}$, including ion channel activation, neuronal excitability, neurotransmitter release, anion-dependent synaptic inhibition, and cerebral blood flow (for review, see Deitmer and Rose, 1996; Chesler, 2003; Attwell et al., 2010). The expression of NBCe1 primarily in astrocytes, but also in oligodendrocytes and some neurons, suggests that NBCe1 (SLC4A4), in addition to NHE, is a major regulator of $\mathrm{pH}$ in the brain (Deitmer and Chesler, 2009; Majumdar and Bevensee, 2010). Due to its electrogenic operation, NBCe1 activity depends on the membrane potential, with depolarization promoting inward transport, and hyperpolarization promoting outward transport, of $\mathrm{Na}^{+}$and $\mathrm{HCO}_{3}^{-}$. Therefore, NBCe1 is capable of operating as either a base loader or an acid loader, and may also help to buffer the extracellular space (Deitmer, 1991; Rose and Deitmer, 1994). This may be significant for controlling neuronal activity via $\mathrm{pH}$-dependent channel gating and efficacy of synaptic inhibition, and hence may contribute to suppression of epileptiform hyperactivity (Ransom, 2000; Choi et al., 2012). Consistent with this view, homozygous mutations in SLC4A4 were reported to be associated with familial migraine, possibly through dysregulation of synaptic $\mathrm{pH}$ (Suzuki et al., 2010). Our present study suggests that the high apparent bicarbonate transport sensitivity in cortical astrocytes might be specialized for acidotic conditions, when the $\left[\mathrm{HCO}_{3}^{-}\right]$ in the tissue may fall considerably, as occurs during neuronal activity-induced acidosis and during pathophysiological conditions such as ischemia.

Synaptic clefts may acidify considerably, dependent on the rate of presynaptic activity and synaptic morphology, during exocytosis of acidic neurotransmitter vesicles (Miesenböck et al., 1998), which in turn suppresses presynaptic calcium current and hence modulates synaptic transmitter release as has been shown in mammalian cone photoreceptors (DeVries, 2001). Extracellular acidification may cause substantial inhibition of NMDA glutamate receptors in cerebellar neurons (Traynelis and CullCandy, 1990), which may be aggravated or counteracted by $\mathrm{HCO}_{3}^{-}$transport into or out of neighboring astrocytes, and thus may function as either negative- or positive-feedback signals for neuronal activity.

In ischemia, the extracellular $\mathrm{pH}$ may drop to as low as 6.7 (Rossi et al., 2007), which can aggravate pathological conditions by activating acid-sensing cation channels (Wemmie et al., 2006), and would reduce the extracellular bicarbonate concentration to as low as $4.8 \mathrm{~mm}$. Though the apparent $K_{\mathrm{m}}$ value of NBCe1, which we report here to be $0.65 \mathrm{~mm}$, the membrane depolarization as- 
sociated with ischemia can alter the $V_{\max }$ of NBCe1 and enable inward bicarbonate transport from an acidic extracellular space. Traumatic brain injury, for example, may cause ischemia, impaired cerebral blood flow, edema, and excitotoxicity, all of which can be associated with brain acidosis (Gupta et al., 2004; Clausen et al., 2005). Bicarbonate administration, on the other hand, has been shown to attenuate the severity of traumatic brain injury in a lateral fluid percussion injury model in mice (Yin et al., 2013).

Under isocapnic conditions $\left(5 \% \mathrm{CO}_{2}\right)$, the extracellular $\left[\mathrm{HCO}_{3}^{-}\right]$would drop to near $1 \mathrm{~mm}$ when external $\mathrm{pH}$ decreases to 6.0 ; on the other hand, a similarly low $\left[\mathrm{HCO}_{3}^{-}\right]$could be achieved at a $\mathrm{pH}$ of 6.7 under hypocapnic conditions $\left(1 \% \mathrm{CO}_{2}\right)$. Although these low $\mathrm{pH} / \mathrm{CO}_{2} / \mathrm{HCO}_{3}^{-}$levels are expected to occur only transiently in cytosolic and extracellular compartments of the normal brain, NBCe1, with the properties described here, would be expected to allow significant transport of $\mathrm{HCO}_{3}^{-}$into or out of astrocytes under these conditions.

The high $\mathrm{HCO}_{3}^{-}$sensitivity of NBCel may have functional relevance for a number of reasons, including the following: (1) NBCe1 could mediate inwardly directed bicarbonate transport, even when extracellular $\left[\mathrm{HCO}_{3}^{-}\right]$is low during acidosis (under physiological and pathophysiological conditions, as described above); (2) bicarbonate transported into astrocytes may activate energy metabolism by increasing the rate of glycolysis (Ruminot et al., 2011; Choi et al. 2012), either by lowering intracellular $\left[\mathrm{H}^{+}\right]$or by activating bicarbonate-dependent cyclic adenylyl cyclase (Chen et al., 2000; Zippin et al., 2001); and (3) the transporter may also be activated at low intracellular bicarbonate concentration and hence reduce or prevent extracellular acidification, which remains to be shown experimentally.

\section{References}

Attwell D, Buchan AM, Charpak S, Lauritzen M, Macvicar BA, Newman EA (2010) Glial and neuronal control of brain blood flow. Nature 468:232243. CrossRef Medline

Becker HM, Deitmer JW (2007) Carbonic anhydrase II increases the activity of the human electrogenic $\mathrm{Na}^{+} / \mathrm{HCO}_{3}^{-}$cotransporter. J Biol Chem 282: 13508-13521. CrossRef Medline

Bröer S, Schneider HP, Bröer A, Rahman B, Hamprecht B, Deitmer JW (1998) Characterization of the monocarboxylate transporter 1 expressed in Xenopus laevis oocytes by changes in cytosolic pH. Biochem J 333:167174. Medline

Brookes N, Turner RJ (1994) $\mathrm{K}^{+}$-induced alkalinization in mouse cerebral astrocytes mediated by reversal of electrogenic $\mathrm{Na}^{+}-\mathrm{HCO}_{3}{ }^{-}$cotransport. Am J Physiol 267:C1633-C1640. Medline

Chen Y, Cann MJ, Litvin TN, Iourgenko V, Sinclair ML, Levin LR, Buck J
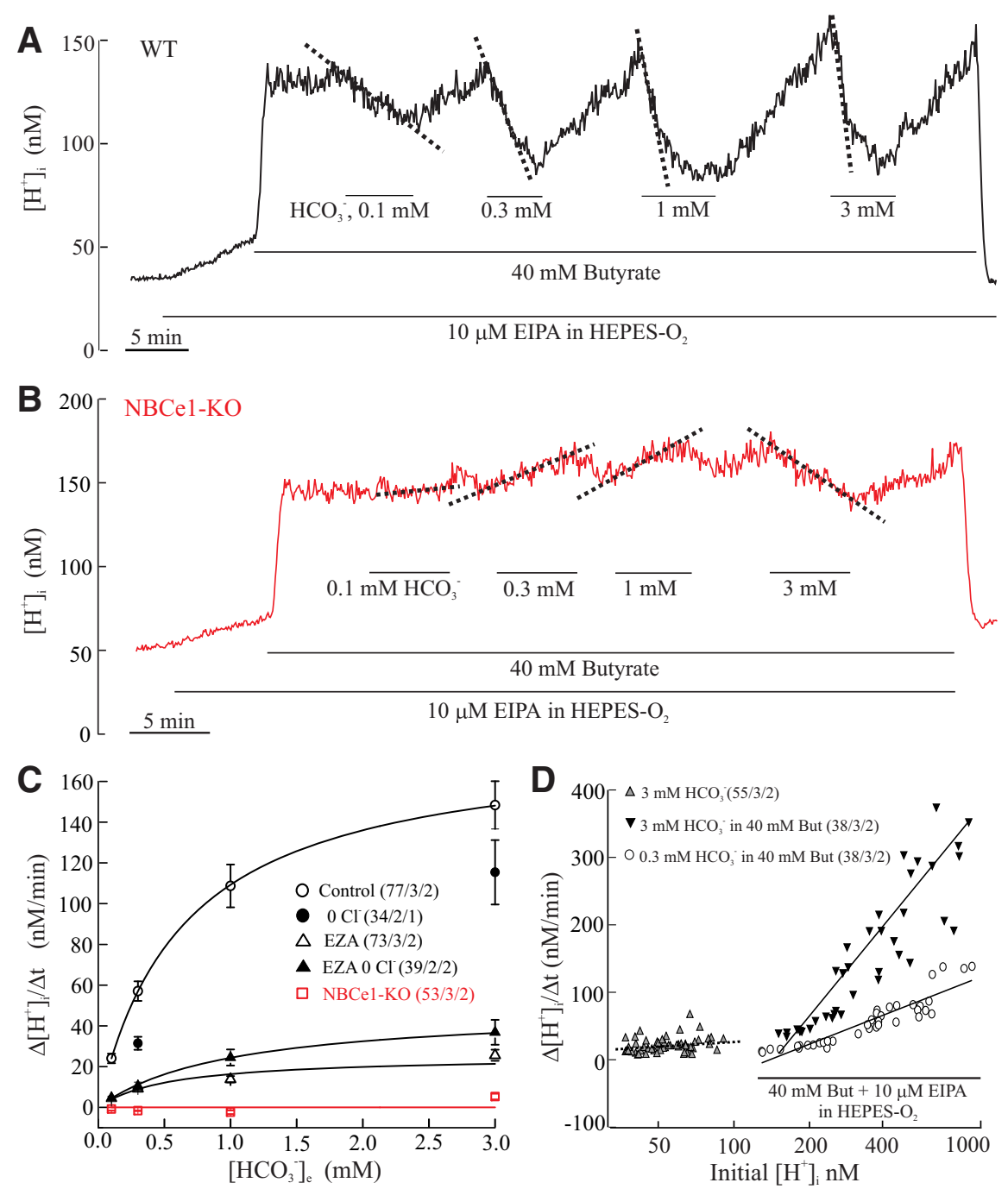

Figure 8. Bicarbonate sensitivity of the intracellular $\mathrm{H}^{+}$concentration at elevated intracellular $\mathrm{H}^{+}$concentration in the presence of butyrate and EIPA. $A, B$, Addition of different low concentrations of $\mathrm{HCO}_{3}^{-}$in HEPES- $\mathrm{O}_{2}$ saline solution containing butyrate $(40 \mathrm{~mm})$ and EIPA $(10 \mu \mathrm{M})$ in WT $(\boldsymbol{A})$ and NBCe1-KO $(\boldsymbol{B})$ astrocytes. $\boldsymbol{C}$, Kinetic analysis of the intracellular $\left[\mathrm{H}^{+}\right]$changes 列

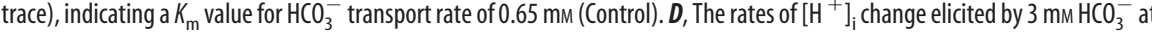
low (resting) initial $\left[\mathrm{H}^{+}\right]_{\mathrm{i}}\left(<100 \mathrm{~nm}\right.$, gray triangles), and at higher initial $\left[\mathrm{H}^{+}\right]_{\mathrm{i}}\left(>100 \mathrm{~nm}\right.$ ) elicited by $0.3 \mathrm{~mm} \mathrm{HCO}_{3}^{-}$(open circles) and by $3 \mathrm{~mm} \mathrm{HCO}_{3}^{-}$(black triangles), showing that these rates are dependent on the $\left[\mathrm{H}^{+}\right]_{\mathrm{i}}$.

(2000) Soluble adenylyl cyclase as an evolutionarily conserved bicarbonate sensor. Science 289:625-628. CrossRef Medline

Chesler M (2003) Regulation and modulation of $\mathrm{pH}$ in the brain. Physiol Rev 83:1183-1221. CrossRef Medline

Choi HB, Gordon GR, Zhou N, Tai C, Rungta RL, Martinez J, Milner TA, Ryu JK, McLarnon JG, Tresguerres M, Levin LR, Buck J, MacVicar BA (2012) Metabolic communication between astrocytes and neurons via bicarbonate-responsive soluble adenylyl cyclase. Neuron 75:10941104. CrossRef Medline

Clausen T, Khaldi A, Zauner A, Reinert M, Doppenberg E, Menzel M, Soukup J, Alves OL, Bullock MR (2005) Cerebral acid-base homeostasis after severe traumatic brain injury. J Neurosurg 103:597-607. CrossRef Medline

Deitmer JW (1991) Electrogenic sodium-dependent bicarbonate secretion by glial cells of the leech central nervous system. J Gen Physiol 98:637655. CrossRef Medline

Deitmer JW, Rose CR (1996) pH regulation and proton signalling by glial cells. Progr Neurobiol 48:73-103. CrossRef

Deitmer JW, Schlue WR (1989) An inwardly directed, electrogenic sodium- 
bicarbonate co-transport in glial cells of the leech central nervous system. J Physiol 411:179-194. Medline

Deitmer JW, Schneider HP (1998) Acid-base transport across the leech giant glial cell membrane at low external bicarbonate concentrations. J Physiol (Lond) 512 2:459-469.

Deitmer JW, Szatkowski M (1990) Membrane potential dependence of intracellular $\mathrm{pH}$ regulation by identified glial cells in the leech central nervous system. J Physiol 421:617-631. Medline

Deitmer JW, Chesler, M. (2009) Neuron-glia pH regulation. In: New encyclopedia of neuroscience, Vol 6 (Squire LR, ed), pp 739-747. Oxford: Academic.

DeVries SH (2001) Exocytosed protons feedback to suppress the $\mathrm{Ca}^{2+}$ current in mammalian cone photoreceptors. Neuron 32:1107-1117. CrossRef Medline

Gawenis LR, Bradford EM, Prasad V, Lorenz JN, Simpson JE, Clarke LL, Woo AL, Grisham C, Sanford LP, Doetschman T, Miller ML, Shull GE (2007) Colonic anion secretory defects and metabolic acidosis in mice lacking the $\mathrm{NBC} 1 \mathrm{Na}^{+} / \mathrm{HCO}_{3}^{-}$cotransporter. J Biol Chem 282:90429052. CrossRef Medline

Gupta AK, Zygun DA, Johnston AJ, Steiner LA, Al-Rawi PG, ${ }^{* *}$ Chatfield D, Shepherd E, Kirkpatrick PJ, Hutchinson PJ, Menon DK (2004) Extracellular brain $\mathrm{pH}$ and outcome following severe traumatic brain injury. J Neurotrauma 21:678-684. CrossRef Medline

Hirrlinger PG, Scheller A, Braun C, Quintela-Schneider M, Fuss B, Hirrlinger J, Kirchhoff F (2005) Expression of reef coral fluorescent proteins in the central nervous system of transgenic mice. Mol Cell Neurosci 30:291-303. CrossRef Medline

Igarashi T, Inatomi J, Sekine T, Cha SH, Kanai Y, Kunimi M, Tsukamoto K, Satoh H, Shimadzu M, Tozawa F, Mori T, Shiobara M, Seki G, Endou H (1999) Mutations in SLC4A4 cause permanent isolated proximal renal tubular acidosis with ocular abnormalities. Nat Genet 23:264-266. CrossRef Medline

Majumdar D, Bevensee MO (2010) Na-coupled bicarbonate transporters of the solute carrier 4 family in the nervous system: function, localization, and relevance to neurologic function. Neuroscience 171:951-972. CrossRef Medline

Miesenböck G, De Angelis DA, Rothman JE (1998) Visualizing secretion and synaptic transmission with $\mathrm{pH}$-sensitive green fluorescent proteins. Nature 394:192-195. CrossRef Medline

Pappas CA, Ransom BR (1994) Depolarization-induced alkalinization (DIA) in rat hippocampal astrocytes. J Neurophysiol 72:2816-2826. Medline

Ransom BR (2000) Glial modulation of neural excitability mediated by extracellular pH: a hypothesis revisited. Prog Brain Res 125:217-228. CrossRef Medline
Romero MF, Boron WF (1999) Electrogenic $\mathrm{Na}^{+} / \mathrm{HCO}_{3}^{-}$cotransporters: cloning and physiology. Annu Rev Physiol 61:699-723. CrossRef Medline

Romero MF, Fong P, Berger UV, Hediger MA, Boron WF (1998) Cloning and functional expression of $\mathrm{rNBC}$, an electrogenic $\mathrm{Na}^{+}-\mathrm{HCO}_{3}^{-}$cotransporter from rat kidney. Am J Physiol 274:F425-F432. Medline

Rose CR, Deitmer JW (1994) Evidence that glial cells modulate extracellular $\mathrm{pH}$ transients induced by neuronal activity in the leech central nervous system. J Physiol 481:1-5. Medline

Rossi DJ, Brady JD, Mohr C (2007) Astrocyte metabolism and signaling during brain ischemia. Nat Neurosci 10:1377-1386. CrossRef Medline

Ruminot I, Gutiérrez R, Peña-Münzenmayer G, Añazco C, Sotelo-Hitschfeld T, Lerchundi R, Niemeyer MI, Shull GE, Barros LF (2011) NBCe1 mediates the acute stimulation of astrocytic glycolysis by extracellular $\mathrm{K}^{+}$. J Neurosci 31:14264-14271. CrossRef Medline

Russell MB, Ducros A (2011) Sporadic and familial hemiplegic migraine: pathophysiological mechanisms, clinical characteristics, diagnosis, and management. Lancet Neurol 10:457-470. CrossRef Medline

Stridh MH, Alt MD, Wittmann S, Heidtmann H, Aggarwal M, Riederer B, Seidler U, Wennemuth G, McKenna R, Deitmer JW, Becker HM (2012) Lactate fluxes in astrocytes enhanced by a non-catalytic action of carbonic anhydrase II. J Physiol 590:2333-2351. CrossRef Medline

Suzuki M, Van Paesschen W, Stalmans I, Horita S, Yamada H, Bergmans BA, Legius E, Riant F, De Jonghe P, Li Y, Sekine T, Igarashi T, Fujimoto I, Mikoshiba K, Shimadzu M, Shiohara M, Braverman N, Al-Gazali L, Fujita T, Seki G (2010) Defective membrane expression of the $\mathrm{Na}^{+}-\mathrm{HCO}_{3}{ }^{-}$ cotransporter NBCe1 is associated with familial migraine. Proc Natl Acad Sci U S A 107:15963-15968. CrossRef Medline

Svichar N, Esquenazi S, Chen HY, Chesler M (2011) Preemptive regulation of intracellular $\mathrm{pH}$ in hippocampal neurons by a dual mechanism of depolarization-induced alkalinization. J Neurosci 31:6997-7004. CrossRef Medline

Traynelis SF, Cull-Candy SG (1990) Proton inhibition of N-methyl-Daspartate receptors in cerebellar neurons. Nature 345:347-350. CrossRef Medline

Wemmie JA, Price MP, Welsh MJ (2006) Acid-sensing ion channels: advances, questions and therapeutic opportunities. Trends Neurosci 29: 578-586. CrossRef Medline

Yin T, Lindley TE, Albert GW, Ahmed R, Schmeiser PB, Grady MS, Howard MA, Welsh MJ (2013) Loss of acid sensing ion channel-1a and bicarbonate administration attenuate the severity of traumatic brain injury. PLoS One 8:e72379. CrossRef Medline

Zippin JH, Levin LR, Buck J (2001) $\mathrm{CO}_{2} / \mathrm{HCO}_{3}^{-}$-responsive soluble adenylyl cyclase as a putative metabolic sensor. Trends Endocrinol Metab 12: 366-370. CrossRef Medline 